\title{
WEIGHTED HARDY-TYPE INEQUALITIES FOR MONOTONE CONVEX FUNCTIONS WITH SOME APPLICATIONS
}

\section{SAJID IQBAL, KRISTINA KRULić HimmelReich AND JOSIP PEČARIĆ}

\begin{abstract}
In this paper, we establish some new refined weighted Hardy-type inequalities involving monotone convex functions. We give the results for some special kernels of RiemannLiouville and Weyl's operators as applications. Also we discuss some related dual cases. At the end, we prove some refined G. H. Hardy-type inequalities for different kinds of fractional integrals and fractional derivatives.
\end{abstract}

Mathematics subject classification (2010): 26D15, 26D10, 26 A33.

Keywords and phrases: Monotone convex function, kernel, fractional derivatives, fractional integrals.

\section{REFERENCES}

[1] G. A. Anastassiou, Fractional Differentiation Inequalities, Springer Science-Businness Media, LLC, Dordrecht, the Netherlands, 2009.

[2] M. ANDRIĆ, J. PEČARIĆ, I. PERIĆ, A multiple Opial type inequality for the Riemann-Liouville fractional derivatives, J. Math. Inequal. 7, 1 (2013), 139-150.

[3] M. ANDRIĆ, J. PEČARIĆ, I. PERIĆ, Improvements of composition rule for Canavati fractional derivative and applications to Opial-type inequalities, Dynam. Systems Appl. 20 (2011), 383-394.

[4] M. Andrić, J. PeČArić, I. PERIĆ, Composition identities for the Caputo fractional derivatives and applications to Opial-type inequalities, Math. Inequal. Appl. (2011), to appear.

[5] D. Baleanu, K. Diethelm, E. Scalas, J. J. Trujillo, Fractional Calculus Models and Numerical Methods. Series on Complexity, Nonlinearity and Chaos, Boston: World Scientific, 2012.

[6] D. Baleanu, O. G. Mustafa, R. P. Agarwal, Asymptotically Linear Solutions for Some Linear Fractional Differential Equations, Abstr. Appl. Anal., Vol. (2010), Article ID 865139, 8 pages.

[7] A. ČIŽMeŠIJA, K. KRUlić, J. PeČARIć, Some new refined Hardy-type inequalities with kernels, J. Math. Inequal. 4, 4 (2010), 481-503.

[8] A. ČIŽMEŠIJA, K. KRULIĆ, J. PeČARIĆ, A new class of general refined Hardy type inequalities with kernels, Rad HAZU, (2013), to appear.

[9] N. Elezović, K. Krulić, J. PeČarić, Bounds for Hardy type differences, Acta Math. Sinica (Eng. Ser.) 27, 4 (2011), 671-684.

[10] G. H. HARDY, Notes on some points in the integral calculus, Messenger. Math. 47, 10 (1918), 145150.

[11] S. IQbal, K. Krulić, J. PeČarić, On an inequality of H. G. Hardy, Journal of Inequalities and Applications 2010 (2010), Artical ID 264347.

[12] S. Kaijser, L. Nikolova, L.-E. Persson, And A. Wedestig, Hardy type inequalities via convexity, Math. Inequal. Appl. 8, 3 (2005), 403-417.

[13] A. A. Kilbas, H. M. SRivastava and J. J. Trujillo, Theory and Application of Fractinal Differential Equations, North-Holland Mathematics Studies, 204, Elsevier, New York-London, 2006.

[14] K. Krulić, J. Pečarić, L. E. Persson, Some new Hardy type inequalities with general kernels, Math. Inequal. Appl. 12 (2009), 473-485.

[15] K. B. Oldham, And J. Spanier, The Fractional Calculus, Academic Press, New York, 1974.

[16] J. Pečarić, F. Proschan, Y. L. Tong, Convex Functions, Partial Orderings and Statistical Applications, Academic Press, Inc. 1992.

[17] I. Podlubny, Fractional Differential Equations, Academic Press, San Diego, 1999. 
[18] S. G. Samko, A. A. Kilbas And O. J. Marichev, Fractional Integral and Derivatives: Theory and Applications, Gordon and Breach Science Publishers, Switzerland, 1993. 